under which the test is made; for example, the breakdown due to discharges in a surrounding medium or due to thermal instability. For the present purpose, the electric strength measured must be independent of such conditions. It appears that a type of breakdown which is a property only of the physical nature of the dielectric and its temperature exists, and may be defined. It has been called intrinsic breakdown, and the corresponding fiold strength is termed the intrinsic electric strength.

Intrinsic breakdown should possess the following properties : $(a)$ it should be independent of thickness over a fairly wide range ; $(b)$ it should be independent of the nature or duration of the electric stress, provided no appreciable change of temperature occurs as a result of the application of the electric stress, and provided the duration is sufficiently long ; $(c)$ the actual discharge should oceur wholly within the dielectric and in the region where the field is most intense. In the experiments it was found convenient to satisfy certain further conditions.

Attempts have been made to identify intrinsic breakdown with various mechanisms. Fröhlich has examined mathematically the equilibrium of an electron in a solid. His theory shows that beyond a certain eritical field-strength an electron may gain energy from the field, and will eventually ionize the lattice. The following deductions can be made from Fröhlich's theory : $(a)$ breakdown should increase with temperature for materials having a low Debye temperature, and be practically independent of temperature for substances with a high Debye temperature; $(b)$ the electric strength should be independent of thickness until the thickness approaches the order of the electronic mean free path, when the electric strength should increase with decrease of thickness.

Many interesting experimental results on mica and on glass, both plain and coloured, are given. The report eoneludes that it has been shown that the electric strength of certain solid dielectrics may be defined in such a way that it is independent of the immersion medium, if any, of the shape of the specimen, of the nature of the electrodes, of the nature of the electric stress provided the maximum value persists for a period of a few micro-seconds, and of the thickness, within certain limits. Excellent diagrams are given showing comparisons between experimental and calculated values, the agreement of the variation of conductance with temperature, and the electric strength of clear ruby muscovitemica.

Based on this report, a paper by A. E. W. Austen and $\$$. Whitehead on the same subject has been communicated to the Royal Society, and is published in the Proceedings (A) of August 28, 1940. It de. seribes some recent measurements of the intrinsic electric strength of certain solid dielectrics. This property of homogeneous solid dielectrics is defined, and methods of measurement suitable for a wide range of materials and conditions are described. A comparison of experimental results with Fröhlich's theory yields the following conclusions: (a) the electric strengths of mica, quartz, potassium bromide. and other alkali halides agree with the theory; $(b)$ the effect of temperature on the electric strengths of mica and potassium bromide agree qualitatively with the theory, while for mica the agreement is also satisfactory quantitatively; $(c)$ the electric strength of mica increases when the thickness is reduced to the order of a few mean free paths, and the agreement is quantitative to the aceuracy with which calculation is possible; (d) fused quartz has a relatively higher electric strength than crystalline quartz, corresponding to the prediction of the theory that disorder increases the electrie strength.

\title{
YELLOW FEVER AND ITS CONTROL*
}

$\mathrm{I}^{\mathrm{N}}$ research on yellow fever to-day, the tiny chick embryo, both as minced tissue culture and as the whole embryo in the shell, is one of the most important of the experimental animals used; but man himself was the only useful experimental animal in the study of this disease until as recently as 1927. Research was thus impeded until that time by the reluctance to expose human volunteers to so dangerous an experimental infection.

The extensive history of attempts to learn how the disease was transmitted reveals, nevertheless, that numerous medical men, without thought to their own comfort or safety, performed the most umpleasant experiments upon themselves. A medical student of the University of Pennsylvania during 1802-1803 placed black vomit and blood serum from yellow fever patients in wounds made in his arms and legs and injected black vomit into animals. Other early experimenters exposed their skins to the soiled clothing, bedding, sweat, black vomit, tissues or blood of vellow fever patients.

In none of these experiments did the yellow fever 'take', and the evidence therefore seemed strong that the disease was not contagious. However, there was so much interest in the disease that a total of

* From a paper by Dr. Wilbur A. Sawyer read on September 17 at the Bicentennial Conference of the Uiniversity of Pennsylvania.
556 articles on it are referred to by a writer of 1827 , reviewing the literature since 1797 .

Although generally accepted proof that a mosquito was the carrier of the disease was not established until the work of Dr. Walter Reed and his associates of the U.S. Army Yellow Fever Commission in 1900 and 1901, Dr. Carlos J. Finlay, of Havana, declared as early as 1881 that he was convinced a mosquito was responsible; and he pointed to the right species, namely, Aerles aegypti. Finlay used 102 human volunteers, who permitted themselves to be bitten by mosquitoes which had sucked the blood of yellow fever patients. That the few illnesses observed among his volunteers could not be accepted as yellow fever is due, Dr. Sawyer suggests, to the fact that Finlay did not let the virus incubate long enough in the mosquitoes before they bit the volunteers.

After Reed's brilliant work showed the way to successful control of yellow fever by eliminating the mosquito, no important new discoveries about the disease were made for another quarter century. This was partly because of the deaths of several human volunteers and the reluctance to use more.

Interest in the possibility of immunization was aroused when, in 1927, Drs. A. Stokes, J. H. Bauer and N. P. Hudson, while making investigations in West Africa, discovered that Asiatic monkeys. 
including the common rhesus monkey, were sus ceptible to yellow fever. Monkeys were immediately used in the research laboratories to study the disease, but during the first few years of this work many scientific workers became infected and several died. Since the development by Drs. Sawyer, W. Lloyd and W. A. Kitchen in 1931 of a vaccine with which all members of the Rockefeller Foundation yellow fever staff are inoculated, there have been no accidental infections among this group. The vaccine consisted of virus cultivated in mice and when injected was accompanied by a protective quantity of blood serum from people who were immune to the disease.

A curious characteristic of the yellow fever virus which has proved of value in developing vaccines is its manifestation of two types of virulence, namely, 'viscerotropism', meaning that it attacks such viscera as the liver, kidneys and heart, and 'neurotropism', meaning that it damages the nervous system. As the virus occurs in Nature it is capable of inflicting both kinds of damage and is therefore said to be 'pantropic'. But man ordinarily suffers only the viscerotropic attack-in his liver, kidneys and heart. The mouse, on the other hand, is susceptible only to the attack on the nerves, and after long passage through a series of mice the yellow fever virus becomes almost purely neurotropic, that is, capable of attacking only nerve tissue and having little power to damage viscera. It was such a modified virus strain that was thought safest to use on man as a vaccine, since man was thought to be relatively resistant to the neurotropic attack. Nevertheless, immune serum was given with the vaccine to prevent the possible occurrence of a yellow fever encephalitis (brain inflammation).

The next step was so to modify the virus strains that they lost their affinity for the nervous tissue also, and this was attempted by growing the virus in oulture media consisting of chick embryos from which the brain and spinal cord had been removed, so that the virus had no nerve tissue on which to grow. The strain thus produced actually has a low virulence for nerve tissue as well as for viscera, and it seems to have undergone a permanent 'evolution' in this direction, for it can now be grown on chick embryos containing the nerve and spinal cord without increasing its virulence for nerves. It is not known, however, whether the fortunate radical change in the virus was due to the absence of brain and cord tissues from the tissue cultures or to an unknown factor. At any rate, this vaccine, produced by workers in the Rockefeller Foundation, and known as $17 \mathrm{D}$, has been used to vaccinate more than a million people in Brazil with results pronounced 'on the whole very satisfactory'.

Another new angle of the yellow fever control campaign is the discovery that not all yellow fever is carried, as had boen thought for many years, by the Aedes cegypti mosquito, which usually frequents the environs of towns and cities. Yellow fever has also been found in the wild areas of central Africa and South America. It is known as jungle yellow fever, and is probably carried by several species of mosquitoes and possibly harboured also by monkeys and other animals. If jungle fever reaches cities infested with the Aedes cegypti it can get into these mosquitoes and start an epidemic of the familiar urban yellow fever. Therefore mosquito control is still an effective weapon. In Brazil, this control includes putting fish in the cistern and water jars to consume the mosquito larvæ.

\section{FORTHCOMING EVENTS}

\author{
Tuesday, November 5
}

Institution of Crvil Enginezis (at Great George Street, S.W.1), at 1.30 p.m.- Sir Leopold H. Savile : Presidential Address.

\section{Wednesday, November 6}

North-East Coast Institution of Enginezrs and ShIPBUIllders (Student SEction) (at Bolbec Hall, Newcastle-upon-Tyne), at 6.45 p.m.-Mr. A. Lawson : "Marine Steering Gears".

\section{APPOINTMENTS VACANT}

APpIICAmons are invited for the following appointments on or before the dates mentioned

Assistant Master for Physics and Biology at the Queen's Royal College, Trinidad-The Secretary (I.P.R./CA), Board of Education, Alexandra House, Kingsway, W.C.2 (November 12).

Assistant Master FOR CHEMISTRY AND PHYsICs at the Queen's College, British Guiana-The Secretary (I.P.R./CA), Board of Education, Alexandra House, Kingsway, W.C.2 (November 12).

Assistant Mrstress for Mathematics n Mataya-The Secretary I.P.R. (CA), Board of Education, Alexandra House, Kingsway, W.C.2 (November 12).

Lecturer in Grography, and a Lecturer in Physios-The LECTURER IN GEOGRAPHY, and a LECTURER IN
Registrar, Portsmouth Municipal College, Portsmouth.

Permanent Trchnical Assistant and a Technicar Assistant IN THE DEPARTMENT OF ECONOMICS-The Principal, Harper Adams Agricultural College, Newport, Shropshire.

LECTURER IN ENGINEERING SUBJECTS in the Department of Mechanical and Civil Engineering and Building, College of Technology and Art, Rotherham-The Director of Education, Education Offlces, Rotherham.

\section{REPORTS AND OTHER PUBLICATIONS}

(not included in the monthly Books Supplement)

\section{Great Britain and Ireland} Proceedings of the Royal Society of Edinburgh, Session 1939-1940.
Vol. 60, Part 3, No. 21: The Swimming and Burrowing Habits of Vol. 60, Part 3, No. 21: The Swimming and Burrowing Habits of the Amphipod Urothoë marina (Bate). By Dr. E. Emrys Watkin. Pp. 271-280. 18. Vol. 60, Part 3, No. 22 : Random Paths in Two and Three Dimensions. By Prof. W. H. McCrea and Dr. F. J. W. Whipple. Pp. 281-298. 18. 6d. Vol. 60, Part 3, No. 23 : An Anslysis of the Influence of Weather upon a Migratory Movement of Birds. By Prof. Glacial Remaing of Reindeer from the Glasgow District. By Dr. M. Macgregor and Prof. James Ritchie. Pp. 322-332, 18. 3d. Vol. 60, Part 3, No. 25: The Effect of Increased Dally Illumination and of Reversed Day and Night on the Cestrous Cycle of the Mouse (Mus musculus). By Dr. R. A. R. Gresson. Pp. 333-343. 18. (Edinburgh : Robert Grant and Son, Ltd.; London: Williams and Norgate,
Ltd.)

\section{Other Countries}

U.S. Treasury Department : Coast Guard. Bulletin No. 28 : International Ice Observation and Ice Patrol Service in the North Atlantic Ocean, Season of 1938. By Floyd M. Soule and G. Van A. Graves. Pp. v+173. (Washington, D.C. : Government Printing Office.) [1410 Annual Report of the All-India Institute of Hygiene and Public Health, Calcutta, 1939. Pp. 81. (Calcutta : Government of India Press.)

[1410

Records of the Indian Museum. Vol. 42, Part 2: On the Systematic Position, Structural Modiflcations, Bionomics and Development of a Remarkable New Family of Cyprinodont Fishes from the Province of Bombay. By C. V. Kulkarni. Pp. 379-423. (Calcutta: Indian Museum.)

$[1410$

Preliminary Annual Report of the Public Health Commissioner with the Government of India for 1939. Pp. ili +75 . (Delhi : Manager
[1410

\section{Catalogues, etc.}

The Wild-Barfleld Heat-Treatment Journal. Vol. 4, No. 26. Pp. 10-22 + iii (Watford: Wild-Barfield Electric Furnaces, Ltd.) Multipoint Temperature Indicator. (E. 15.) Pp. 4. Pyrometer (E. 19.) Pp. 6. (London : Negretti and Zambra.)

A Catalogue of Books and Periodicals on General Natural History including a Selection on Hawking, Hunting, Shooting. (No. 580.) Pp. 40. (London: Bernard Quaritch, Ltd.) 